\title{
Polymorphism of PXR gene associated with the increased risk of drug-induced liver injury in Indonesian pulmonary tuberculosis patients
}

\author{
Z. Zazuli* MPharm, M. I. Barliana† PhD, U. A. Mulyanił MSc, D. A. Perwitasari§ PhD, H. Ng* BPharm and R. Abdulah* PhD \\ ${ }^{*}$ Department of Pharmacology and Clinical Pharmacy, Faculty of Pharmacy, Universitas Padjadjaran, Jatinangor, †Department of Biological Pharmacy, Faculty \\ of Pharmacy, Universitas Padjadjaran, Jatinangor, †Center for Applied Health Technology and Clinical Epidemiology, National Institute of Health Research and \\ Development, Ministry of Health Republic of Indonesia, Jakarta, and §Faculty of Pharmacy, Universitas Ahmad Dahlan, Yogyakarta, Indonesia
}

Received 25 December 2014, Accepted 25 August 2015

Keywords: antituberculosis drugs, drug-induced hepatotoxicity, drug-induced liver injury, polymorphism, PXR

\section{SUMMARY}

What is known and objective: Tuberculosis is still a major infectious disease in Indonesia. Patients are treated mostly using fixed-dose combination treatment in primary public health facilities. The incidence of antituberculosis drug-induced liver injury (AT-DILI) is approximately $10 \%$ among Indonesian tuberculosis patients who used standard fixed combination regimens during the intensive phase of treatment. However, information regarding genetic polymorphism associated with the increase risk of drug-induced liver injury is still limited. The aim of this study was to investigate pregnane $\mathrm{X}$ receptor (PXR) gene polymorphisms as one of the risk factors of AT-DILI.

Methods: In this prospective cohort study, we recruited 106 adult patients diagnosed with pulmonary tuberculosis and treated with category I FDC (fixed-dose combination). The identification of SNP -25385C $>$ T (rs3814055) was conducted by ARMS (amplification refractory mutation system). Hepatotoxicity was defined as ALT and/or AST levels above the normal threshold on the second, fourth and sixth months of monitoring during tuberculosis treatment.

Results and discussion: The logistic regression analysis showed that patients with the TT genotype of PXR gene (rs3814055) significantly had a greater risk of AT-DILI (OR 8.89; 95\% CI 1.36-57.93, $P<0.05)$, compared with those of wild-type CC genotype.

What is new and conclusion: The result suggests that in Indonesian patients with tuberculosis, the risk of having ATDILI was associated with TT genotype of the PXR gene.

\section{WHAT IS KNOWN AND OBJECTIVE}

Tuberculosis (TB) is an infectious disease that is still a major problem in developing countries, including Indonesia. In 2014, the World Health Organization categorized Indonesia as a high-TB-, multi-drug resistant (MDR)-TB-, and human immunodeficiency virus (HIV)-burdened country. There are an estimated 9.0 million incident cases of TB and 1.5 million people died of the disease each year (1.1 million deaths were HIV negative, and 360000 were HIV positive). The corresponding figures for Indonesia are 325 582, and 7964 cases of TB have been identified as new and relapse cases,

Correspondence: R. Abdulah, PhD, Department of Pharmacology and Clinical Pharmacy, Faculty of Pharmacy, Universitas Padjadjaran, Jl. Raya Bandung Sumedang KM. 21, Jatinangor 45363, Indonesia. Tel. and fax: +62 22 7796200; e-mail: abdulahrizky@gmail.com respectively. ${ }^{1}$ Given this high burden of disease, the government of Indonesia is focusing on the control and elimination of TB. One of the efforts is through the directly observed treatment, short-course strategy (DOTS) programme.

One of the main concerns in antituberculosis drugs (ATDs) is drug-induced liver injury (DILI) or hepatotoxicity caused by drugs. $^{2}$ Of the first-line anti-TB drugs, isoniazid, pyrazinamide and rifampicin can all cause liver damage (drug-induced hepatitis). ${ }^{3}$ In addition, rifampicin can cause asymptomatic jaundice without evidence of hepatitis. ${ }^{3}$ A previous publication has shown that the incidence of antituberculosis drug-induced liver injury (AT-DILI) is around $10 \%$ among Indonesian TB patients treated with standard fixed combination regimens during the intensive phase of treatment. ${ }^{4}$ Many researchers have reported on specific gene polymorphisms as risk factors for those hepatotoxic effects. Some of the reported genes are N-acetyltransferase 2 (NAT2), ${ }^{5-10}$ cytochrome P450 2E1 (CYP2E1), ${ }^{9,11,12}$ glutathione S-transferase mu-1 (GSTM1) $)^{9,10,13}$ and glutathione S-transferase theta (GSTT). ${ }^{9,13}$ Other genes also reported to be potential predictors of ATDs-DILI are pregnane $\mathrm{X}$ receptor $(P X R)$, glutathione S-transferase alpha-1 (GSTA1), manganese superoxide dismutase (MnSOD, SOD2), UDP-glucuronosyltransferase (UGT), nitric oxide synthase 2A (NOS2A), BTB and CNC homology 1 (BACH1), Maf basic leucine zipper protein $(M A F K)$, and human leucocyte antigen $(H L A){ }^{14-18}$

We examined PXR gene polymorphism because ligand formation between rifampicin and PXR could trigger the expression of various genes, including various cytochromes and carboxylesterases that may be relevant to the metabolism of isoniazid in producing hepatotoxic metabolites. PXR plays a role in the regulation of a number of hepatic and intestine genes involved in detoxification and elimination of xenobiotics. ${ }^{19}$ The polymorphisms are generally located in the $5^{\prime}$-flanking region of the target genes. $^{20}$ PXR activates various genes through binding and heterodimer formation with the retinoid $X$ receptor (RXR). PXR ligands stimulates the expression of genes involved in xenobiotics oxidation (phase I), conjugation (phase II) and transport (phase III) in the liver. PXR is involved in phase I metabolism through the expression of CYP2B6, CYP2C8,CYP2C9, CYP2B9 and CYP2C19. ${ }^{21-25}$ Moreover, PXR is involved in phase II metabolism through the expression of glutathione S-transferase (GST), sulfotransferase, UDP-glucuronosyltransferase and carboxylesterase. ${ }^{26-31}$ PXR is involved in phase III through the expression of organic anion transporting polypeptide 2(OATP2) and multiple drug resistance protein 2 (MRP2). ${ }^{32-34}$ This study aimed to investigate possible associations of PXR gene polymorphisms with the increased risk of ATDs-DILI. 


\section{METHODS}

\section{Patients}

A total of 106 patients with active lung TB who visited selected primary public health facilities in Bandar Lampung and Yogyakarta were enrolled consecutively and followed up in this prospective cohort study. Inclusion criteria were as follows: (i) adult patients (over 18 years of age) newly diagnosed with active lung TB, (ii) treated with fixed-dose combination of antituberculosis drugs (FDC-ATD) category I using directly observed treatment, short-course strategy (DOTS) and (iii) have agreed to the terms in the written informed consent. Patients with any of the following conditions were excluded from the study: (i) positive HIV/AIDS, (ii) abnormal serum ALT and AST levels over twice upper limit of normal (ULN) value before treatment with ATD, (iii) with hepatitis or have a history of hepatitis, (iv) haemoglobin serum $<8 \mathrm{mg} / \mathrm{dL}$, (v) not having ATDs for over 2 weeks, (vi) have a history of kidney disease and (vii) refusal to blood collection.

All patients received FDC-ATD category I intensive phase (rifampicin $150 \mathrm{mg}$, isoniazid $75 \mathrm{mg}$, pyrazinamide $400 \mathrm{mg}$ and ethambutol $275 \mathrm{mg}$ per tablet) and FDC-ATD category I continuation phase (rifampicin $150 \mathrm{mg}$ and isoniazid $150 \mathrm{mg}$ ) in 6 months of therapy. The dosage of ATDs was selected according to the patients' weight. ALT and AST serum levels were obtained five times: before ATD treatment, after completing the second, the fourth, the sixth months of ATD therapy and 1 month after the patient finished the last ATDs therapy. Antituberculosis druginduced liver disease (ATD-DILI) was designated as an increase in serum ALT and AST levels above the ULN after ATDs treatment, according to the criteria of drug-induced liver injuries developed by Drug-Induced Liver Injury Network (DILIN), National Institute of Diabetes and Digestive and Kidney Diseases (NIDDK), and Division of Specialized Information Services of the National Library of Medicine (NLM), and National Institutes of Health and Common Toxicity Criteria for Adverse Events 4.0 version (CTCAE v.4.0, Bethesda, MD, USA). ${ }^{35}$

The written informed consent was obtained from each patient enrolled in this study. This study protocol conformed to the ethical guidelines of the 1975 Declaration of Helsinki and was approved by the Ethics Committee for Health Research, National Institute of Health Research and Development, Ministry of Health, Republic of Indonesia.

\section{Single Nucleotide Polymorphism genotyping}

DNA was extracted from the peripheral blood sample collected from each patient using the standard proteinase $\mathrm{K}$ digestion and GeneJET Genomic DNA Purification Kit (Thermo Scientific ${ }^{\circledR}$, Walthman, MA, USA.). Polymerase chain reaction-amplification refractory mutation system (PCR-ARMS) was used to detect the 25385C $>$ T (rs3814055) PXR polymorphisms located in the $5^{\prime} \mathrm{UTR}$ promoter. The two primer sets were as follows: forward $5^{\prime}$ TTTTGGCAATCCCAGGTTT-3' to detect PXR polymorphic gene (F-primer - 1) and 5'-TTTTGGCAATCCCAGGTTC-3' to confirm normal fragment gene (F-primer - 2); reverse $5^{\prime}$-CGAATGTGGTGGATACCAG-3'. PCR was carried out using 5x FIREPol ${ }^{\circledR}$ Master Mix Ready from Solis BioDyne ${ }^{\circledR}$ (Tartu, Estonia), according to the manufacturer's instruction. Initial denaturation at $95{ }^{\circ} \mathrm{C}$ for $4 \mathrm{~min}$ was followed by 40 cycles of denaturation at $95^{\circ} \mathrm{C}$ for $30 \mathrm{~s}$, annealing at $59.7{ }^{\circ} \mathrm{C}$, extension at $72{ }^{\circ} \mathrm{C}$ for $1 \mathrm{~min}$, with final extension at $72{ }^{\circ} \mathrm{C}$ for $7 \mathrm{~min}$. The products obtained were electrophoresed on $2 \%$ agarose gels. Polymorphic gene TT showed 219-bp PCR product only when it was identified using F-1 forward primer, non-polymorphic gene CC showed $219 \mathrm{bp}$ only when it was identified using F-2 reverse primer, and heterozygote gene CT showed $219 \mathrm{bp}$ when it was identified using both forward primers.

\section{Statistical analysis}

Allele frequencies were calculated, and the agreement between the allele frequencies and Hardy-Weinberg equilibrium was tested using a chi-square test (d.f. $=1$ ) for each locus. Odds ratios (ORs) and $95 \%$ confidence intervals (95\% CIs) were calculated using binomial logistic regression analysis, adjusting for sex and age. The baseline ALT and AST differences among genotype groups were determined using the Kruskal-Wallis test. Statistical analyses were performed using a data analysis freeware.

\section{RESULTS AND DISCUSSION}

\section{Results}

The result of UV gel visualization is shown in Fig. 1. Homozygotes TT and CC showed single bands on F-primer 1 and F-primer 2, respectively. Heterozygote CT showed double bands with the Fprimer 1 and F-primer 2.

Seven patients $(6 \cdot 6 \%)$ were TT homozygotes, 32 patients (30.19\%) were CT heterozygotes, and most patients $(67 ; 63.21 \%)$ were wild-type CC homozygotes. The genotype frequencies were not different from those predicted by the Hardy-Weinberg equation (Table 1).

Table 2 shows that there was no statistical difference in ALT and AST baseline levels among both male and female patients with different genotypes $(P>0.05)$. The mean of ALT and AST levels increased at the end of the first 2 months of ATD therapy or after completion of the intensive phase and decreased during the continuous phase (Table 3). Most of the patients (71 patients; $66.98 \%$ ) experienced no hepatotoxicity, but 35 patients showed elevated transaminase levels. The transaminase elevation was seen in 33 patients $(31 \cdot 13 \%)$ with mild hepatotoxicity $(1+)$ and 2 patients $(1 \cdot 89 \%)$ with moderate hepatotoxicity (2+) (Table 4$)$.

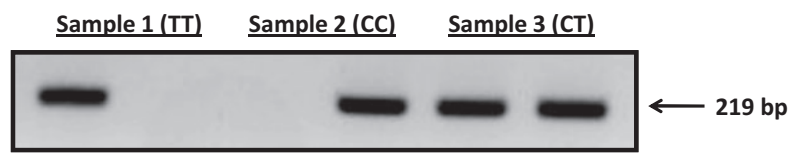

Fig. 1. UV visualization result of $25385 \mathrm{C}>\mathrm{T}$ (rs3814055) polymorphisms.

Table 1. Comparison of observed and expected genotype frequency based on Hardy-Weinberg equilibrium

\begin{tabular}{llcc}
\hline Genotypes & Observed & Expected & $P$ value \\
\hline CC & 67 & 65 & 0.25 \\
CT & 32 & 36 & \\
TT & 7 & 5 & \\
\hline
\end{tabular}


Table 2. Characteristics of patients according to genotype

\begin{tabular}{|c|c|c|c|c|c|c|c|}
\hline & \multicolumn{6}{|l|}{ Genotype } & \multirow[b]{3}{*}{$P$ value } \\
\hline & \multicolumn{2}{|l|}{ TT } & \multicolumn{2}{|l|}{$\mathrm{CT}$} & \multicolumn{2}{|l|}{$\mathrm{CC}$} & \\
\hline & $n(\%)$ & Mean \pm SD & $n(\%)$ & Mean \pm SD & $n(\%)$ & Mean \pm SD & \\
\hline \multicolumn{8}{|l|}{ Sex } \\
\hline Male & $5(71.43)$ & & $18(56 \cdot 25)$ & & $49(73 \cdot 13)$ & & \\
\hline Female & $2(28.57)$ & & $14(43 \cdot 75)$ & & $18(26 \cdot 87)$ & & \\
\hline Total & $7(100 \cdot 00)$ & & $32(100 \cdot 00)$ & & $67(100 \cdot 00)$ & & \\
\hline \multicolumn{8}{|c|}{ Age group (years) } \\
\hline $18-45$ & $4(57 \cdot 14)$ & & $23(71.88)$ & & $46(68 \cdot 66)$ & & \\
\hline $46-55$ & $1(14 \cdot 29)$ & & $6(18.75)$ & & $13(19.40)$ & & \\
\hline$>55$ & $2(28.57)$ & & $3(9 \cdot 38)$ & & 8 (11.94) & & \\
\hline Total & $7(100 \cdot 00)$ & & $32(100 \cdot 00)$ & & $67(100 \cdot 00)$ & & \\
\hline \multicolumn{8}{|c|}{ ALT baseline } \\
\hline Male & & $31.20 \pm 8.55$ & & $24.56 \pm 2.87$ & & $21.22 \pm 1.96$ & 0.195 \\
\hline Female & & $12.00 \pm 2.00$ & & $17.07 \pm 3.13$ & & $14.94 \pm 1.38$ & 0.767 \\
\hline \multicolumn{8}{|c|}{ AST baseline } \\
\hline Male & & $33.60 \pm 8.70$ & & $26.00 \pm 3.00$ & & $21.49 \pm 1.35$ & 0.053 \\
\hline Female & & $17 \cdot 50 \pm 2.50$ & & $21 \cdot 21 \pm 2.63$ & & $20.67 \pm 1.40$ & 0.754 \\
\hline
\end{tabular}

Table 3. Serum aminotransferase level cohort data according to sex

\begin{tabular}{lrrr}
\hline & Min $(\mathrm{g} / \mathrm{dL})$ & Max $(\mathrm{g} / \mathrm{dL})$ & Mean $\pm \mathrm{SE}(\mathrm{g} / \mathrm{dL})$ \\
\hline Male & & & \\
ALT & & & \\
$\quad$ Baseline & $5 \cdot 00$ & $91 \cdot 00$ & $22 \cdot 75 \pm 1 \cdot 63$ \\
2nd month & $9 \cdot 00$ & $218 \cdot 00$ & $25 \cdot 43 \pm 3 \cdot 18$ \\
4th month & $5 \cdot 00$ & $46 \cdot 00$ & $18 \cdot 00 \pm 0 \cdot 97$ \\
6th month & $5 \cdot 00$ & $77 \cdot 00$ & $19 \cdot 31 \pm 1 \cdot 48$ \\
8th month & $7 \cdot 00$ & $76 \cdot 00$ & $20 \cdot 96 \pm 1 \cdot 39$ \\
AST & & & \\
Baseline & $8 \cdot 00$ & $70 \cdot 00$ & $23 \cdot 46 \pm 1 \cdot 36$ \\
2nd month & $10 \cdot 00$ & $167 \cdot 00$ & $27 \cdot 76 \pm 2 \cdot 27$ \\
4th month & $11 \cdot 00$ & $46 \cdot 00$ & $23 \cdot 81 \pm 0 \cdot 87$ \\
6th month & $9 \cdot 00$ & $63 \cdot 00$ & $24 \cdot 12 \pm 1 \cdot 03$ \\
8th month & $9 \cdot 00$ & $51 \cdot 00$ & $22 \cdot 93 \pm 0 \cdot 88$ \\
Female & & & \\
ALT & & & \\
Baseline & $8 \cdot 00$ & $55 \cdot 00$ & $15 \cdot 65 \pm 1 \cdot 47$ \\
2nd month & $8 \cdot 00$ & $49 \cdot 00$ & $18 \cdot 91 \pm 1 \cdot 79$ \\
4th month & $5 \cdot 00$ & $59 \cdot 00$ & $17 \cdot 35 \pm 2 \cdot 19$ \\
6th month & $6 \cdot 00$ & $74 \cdot 00$ & $19 \cdot 74 \pm 3 \cdot 05$ \\
8th month & $5 \cdot 00$ & $64 \cdot 00$ & $20 \cdot 74 \pm 2 \cdot 24$ \\
AST & & & \\
Baseline & $11 \cdot 00$ & $52 \cdot 00$ & $20 \cdot 71 \pm 1 \cdot 30$ \\
2nd month & $10 \cdot 00$ & $49 \cdot 00$ & $22 \cdot 91 \pm 1 \cdot 49$ \\
4th month & $10 \cdot 00$ & $53 \cdot 00$ & $23 \cdot 18 \pm 1 \cdot 63$ \\
6th month & $8 \cdot 00$ & $67 \cdot 00$ & $23 \cdot 47 \pm 2 \cdot 13$ \\
8th month & $13 \cdot 00$ & $44 \cdot 00$ & $23 \cdot 12 \pm 1 \cdot 19$ \\
& & & \\
\hline
\end{tabular}

The risk of having ATD-DILI was significantly associated with the TT genotype. For this genotype, the risk of having an ATDDILI was 8.89 -fold (OR: 8.89; $95 \%$ CI: $1.36-57.93 ; P=0.022$ ) that of
Table 4. Frequency of hepatotoxicity according to severity of drug-induced hepatotoxicity

\begin{tabular}{lc}
\hline Drug-induced Hepatotoxicity Level & $n(\%)$ \\
\hline $1+$, Mild $(<2 \cdot 5 \times \mathrm{ULN})$ & $33(31 \cdot 13)$ \\
$2+$, Moderate $(2 \cdot 5-5 \times \mathrm{ULN})$ & $2(1.89)$ \\
No hepatotoxicity & $71(66 \cdot 98)$ \\
Total & $106(100 \cdot 00)$ \\
\hline
\end{tabular}

the wild-type (CC genotype) (Table 5). The results also show that the combined (CT + TT) genotype had a tendency for higher incidence of ATD-DILI in comparison with the wild-type CC genotype (OR: 1.32; 95\% CI: 0.56-3.14; $P=0.525$ ). We also found that the risk of an ATD-DILI in females was 2.64-fold (OR: 2.64; 95\% CI: $1.06-6.57 ; P=0.036)$ that of males.

\section{Discussion}

We found that there was a significant association between the variant TT homozygote of PXR $(-25385 \mathrm{C}>\mathrm{T}$; rs3814055) and the risk of AT-DILI. This result is consistent with results reported by Andrews et al. ${ }^{36}$ who reported that a different PXR polymorphism at the same location was significantly associated with liver injury caused by flucloxacillin, a PXR agonist. Andrews et al. concluded that the CC genotype was associated with the risk of flucloxacillininduced liver injury. However, a previous study conducted in Europe and South Asia reported no association between ATDs and PXR gene polymorphism in patients. ${ }^{37}$

As genetic polymorphism is only one of the many factors that may contribute to drug-induced hepatotoxicity, its significance requires further testing. ${ }^{38}$ Rifampicin is a PXR agonist. PXR is involved in the regulation of bile acid and cholesterol homeostasis. 
Table 5. Results of logistic regression analysis

\begin{tabular}{|c|c|c|c|c|}
\hline & \multirow{2}{*}{$\begin{array}{l}\text { Non-hepatotoxic } \\
n(\%)\end{array}$} & \multicolumn{3}{|c|}{ Hepatotoxic } \\
\hline & & $n(\%)$ & OR (CI 95\%) & $P$ value \\
\hline \multicolumn{5}{|l|}{ Genotype } \\
\hline $\mathrm{CC}$ & $47(66 \cdot 2)$ & $20(57 \cdot 14)$ & $1 \cdot 00^{\mathrm{a}}$ & \\
\hline $\mathrm{TT}+\mathrm{CT}$ & $24(33 \cdot 8)$ & $15(42 \cdot 86)$ & $1.32(0.56-3.14)$ & 0.525 \\
\hline $\mathrm{TT}$ & $2(2 \cdot 82)$ & $5(14 \cdot 29)$ & $8.89(1.36-57.93)$ & $0.022 *$ \\
\hline $\mathrm{CT}$ & $22(30.99)$ & $10(28.57)$ & $0.87(0.33-2 \cdot 27)$ & 0.770 \\
\hline \multicolumn{5}{|l|}{ Sex } \\
\hline Male & $53(74 \cdot 65)$ & $19(54 \cdot 29)$ & $1 \cdot 00^{\mathrm{a}}$ & \\
\hline Female & $18(25 \cdot 35)$ & $16(45 \cdot 71)$ & $2.64(1.06-6.57)$ & $0.036^{*}$ \\
\hline Age & & & $0.97(0.93-0.99)$ & $0 \cdot 044^{*}$ \\
\hline
\end{tabular}

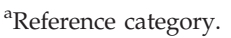

* Statistically significant $P<0.05$.

Some of the bile acids are toxic. Therefore, the regulation by PXR of the expression of proteins involved in both phase I and phase II drug metabolism and transport requires further investigation. ${ }^{39}$ Murine studies with the humanized pregnane $X$ receptor ( $h P X R$ ) suggested that rifampicin and isoniazid combination therapy leads to accumulation of protoporphyrin IX, an endogenous hepatotoxin through a mechanism involving PXR's effect on the haem biosynthesis pathway. ${ }^{40}$

This study also indicates that females are significantly more likely to show ATD-DILI than males. This is consistent with some previous studies which showed that female patients were more likely to show hepatotoxicity. ${ }^{41-43}$ They also reportedly show a higher risk of hepatotoxicity with nitrofurantoin, erythromycin, flucloxacillin, minocycline and isoniazid. ${ }^{44}$ Drug-induced hepatotoxicity in females tends to be hepatocellular with vascular damage on the centrilobular vein. ${ }^{44,45}$ The presence of genetic abnormality in the mitochondria is also said to be a major determinant of idiosyncratic drug-induced hepatotoxicity especially in women and the elderly. ${ }^{46}$

Our study has some limitations because we did not use other liver function parameters such as total serum bilirubin, serum ALP, INR and GGT. Their measurements would have been useful in defining liver function and the severity of hepatotoxicity better. We were also not able to assess other confounding factors, such as exposure to hepatotoxic agents including commonly encountered items such as acetaminophen, potentially hepatotoxic herbal and food products, and other chemicals in the patient's environment. The small number of PXR T homozygotes calls for a larger confirmatory study.

\section{WHAT IS NEW AND CONCLUSION}

We found a significant association between the PXR TT variant (-25385C $>$ T; rs3814055) and the AT-DILI. Whether testing for PXR genotype will provide reliable predictions of AT-DILI requires further validation.

\section{ACKNOWLEDGEMENT}

The authors thank Jarir At Thobari, Anas Subarnas, Keri Lestari, Tiana Milanda, Iswandi Darwis, Soraya Rahmanisa, Syachroni and Muhammad Khairuman for their guidance and technical support in this study.

\section{CONFLICT OF INTEREST}

None declared.

\section{SOURCE OF FUNDING}

The study was funded by the Centre for Applied Health Technology and Clinical Epidemiology, The National Institute of Health Research and Development, Ministry of Health Republic of Indonesia.

\section{REFERENCES}

1. Organization WH. 2014. Global tuberculosis report 2014. Available at: http://www.who. int/tb/publications/global_report/en/ (acc essed 30 October 2014).

2. Saukkonen JJ, Cohn DL, Jasmer RM et al. An official ATS statement: hepatotoxicity of antituberculosis therapy. Am J Respir Crit Care Med, 2006;174:935-952.

3. Organization WH. 2010. Treatment of tuberculosis guideline. Available at: http:// www.who.int/tb/publications/2010/978 9241547833/en/ (accessed 28 March 2014).

4. Atthobari J, Mulyani UA, Perwitasari DA, Darwis I. 2013. Early drug induced liver injury after intensive phase of tb treatment in Indonesia: Primary care centers and lung hospital study. In The 13th International Society of Pharmacovigilance Annual Meeting Pisa: Drug Safety, 36:864.

5. Huang YS, Chern HD, Su WJ et al. Polymorphism of the n-acetyltransferase 2 gene as a susceptibility risk factor for antituberculosis drug-induced hepatitis. Hepatology, 2002;35:883-889.

6. Sun F, Chen Y, Xiang Y, Zhan S. Drugmetabolising enzyme polymorphisms and predisposition to anti-tuberculosis drug-induced liver injury: a meta-analysis. Int J Tuberc Lung Dis, 2008;12:994-1002.

7. Ben Mahmoud L, Ghozzi H, Kamoun A et al. Polymorphism of the n-acetyltransferase 2 gene as a susceptibility risk factor for antituberculosis drug-induced hepatotoxicity in tunisian patients with tuberculosis. Pathol Biol (Paris), 2012;60:324-330.

8. Wang PY, Xie SY, Hao Q, Zhang C, Jiang BF. Nat2 polymorphisms and susceptibility to anti-tuberculosis drug-induced liver injury: a meta-analysis. Int J Tuberc Lung Dis, 2012;16:589-595.

9. Forestiero FJ, Cecon L, Hirata $\mathrm{MH}$, de Melo FF, Cardoso RF, Cerda A, Hirata
RD. Relationship of nat2, cyp2e1 and gstm1/gstt1 polymorphisms with mild elevation of liver enzymes in Brazilian individuals under anti-tuberculosis drug therapy. Clin Chim Acta, 2013;415: 215-219.

10. Rana SV, Sharma SK, Ola RP, Kamboj JK, Malik A, Morya RK, Sinha SK. N-acetyltransferase 2, cytochrome p4502e1 and glutathione s-transferase genotypes in antitubercular treatment-induced hepatotoxicity in North Indians. J Clin Pharm Ther, 2014;39:91-96.

11. Lee SW, Chung LS, Huang HH, Chuang TY, Liou YH, Wu LS. Nat2 and cyp2e1 polymorphisms and susceptibility to first-line anti-tuberculosis drug-induced hepatitis. Int J Tuberc Lung Dis, 2010;14:622-626.

12. Deng R, Yang T, Wang Y, Tang N. Cyp2e1 rsai/psti polymorphism and risk of antituberculosis drug-induced liver injury: a 
meta-analysis. Int $J$ Tuberc Lung Dis, 2012;16:1574-1581.

13. Tang SW, Lv XZ, Zhang Y et al. Cyp2e1, gstm1 and gstt1 genetic polymorphisms and susceptibility to antituberculosis druginduced hepatotoxicity: a nested case-control study. J Clin Pharm Ther, 2012;37: 588-593.

14. Liddle C, Goodwin B. Regulation of hepatic drug metabolism: role of the nuclear receptors pxr and car. Semin Liver Dis, 2002;22:115-122.

15. Brind AM, Hurlstone A, Edrisinghe D, Gilmore I, Fisher N, Pirmohamed M, Fryer AA. The role of polymorphisms of glutathione s-transferases gstm1, m3, p1, t1 and a1 in susceptibility to alcoholic liver disease. Alcohol Alcohol, 2004;39:478-483.

16. Zhang B, Xie W, Krasowski MD. Pxr: a xenobiotic receptor of diverse function implicated in pharmacogenetics. Pharmacogenomics, 2008;9:1695-1709.

17. Padda MS, Sanchez M, Akhtar AJ, Boyer JL. Drug-induced cholestasis. Hepatology, 2011;53:1377-1387.

18. Huang YS. Recent progress in genetic variation and risk of antituberculosis druginduced liver injury. J Chin Med Assoc, 2014;77:169-173.

19. Kliewer SA, Goodwin B, Willson TM. The nuclear pregnane $\mathrm{x}$ receptor: a key regulator of xenobiotic metabolism. Endocr Rev, 2002;23:687-702.

20. Wang H, LeCluyse EL. Role of orphan nuclear receptors in the regulation of drugmetabolising enzymes. Clin Pharmacokinet, 2003;42:1331-1357.

21. Xie W, Barwick JL, Simon CM et al. Reciprocal activation of xenobiotic response genes by nuclear receptors sxr/pxr and car. Genes Dev, 2000;14:3014-3023.

22. Gerbal-Chaloin S, Pascussi JM, PichardGarcia L et al. Induction of cyp2c genes in human hepatocytes in primary culture. Drug Metab Dispos, 2001;29:242-251.

23. Goodwin B, Moore LB, Stoltz CM, McKee DD, Kliewer SA. Regulation of the human cyp2b6 gene by the nuclear pregnane $x$ receptor. Mol Pharmacol, 2001;60:427-431.

24. Synold TW, Dussault I, Forman BM. The orphan nuclear receptor sxr coordinately regulates drug metabolism and efflux. Nat Med, 2001;7:584-590.

25. Gerbal-Chaloin S, Daujat M, Pascussi JM, Pichard-Garcia L, Vilarem MJ, Maurel P. Transcriptional regulation of cyp2c9 gene. Role of glucocorticoid receptor and constitutive androstane receptor. I Biol Chem, 2002;277:209-217.

26. Madhu C, Klaassen CD. Protective effect of pregnenolone-16 alpha-carbonitrile on acetaminophen-induced hepatotoxicity in hamsters. Toxicol Appl Pharmacol,1991;109:305-313.

27. Hosokawa M, Hattori K, Satoh T. Differential responses of rat hepatic microsomal carboxylesterase isozymes to glucocorticoids and pregnenolone 16 alpha-carbonitrile. Biochem Pharmacol, 1993;45:2317-2322.

28. Liu L, Klaassen CD. Regulation of hepatic sulfotransferases by steroidal chemicals in rats. Drug Metab Dispos, 1996;24:854-858.

29. Dunn RT 2nd, Gleason BA, Hartley DP, Klaassen CD. Postnatal ontogeny and hormonal regulation of sulfotransferase sult1b1 in male and female rats. J Pharmacol Exp Ther, 1999;290:319-324.

30. Runge-Morris M, Wu W, Kocarek TA. Regulation of rat hepatic hydroxysteroid sulfotransferase (sult2-40/41) gene expression by glucocorticoids: evidence for a dual mechanism of transcriptional control. Mol Pharmacol, 1999;56:1198-1206.

31. Falkner KC, Pinaire JA, Xiao GH, Geoghegan TE, Prough RA. Regulation of the rat glutathione s-transferase a2 gene by glucocorticoids: involvement of both the glucocorticoid and pregnane $\mathrm{x}$ receptors. Mol Pharmacol, 2001;60:611-619.

32. Courtois A, Payen L, Guillouzo A, Fardel O. Up-regulation of multidrug resistance-associated protein 2 (mrp2) expression in rat hepatocytes by dexamethasone. FEBS Lett, 1999;459:381-385.

33. Fromm MF, Kauffmann HM, Fritz P et al. The effect of rifampin treatment on intestinal expression of human mrp transporters. Am J Pathol, 2000;157:1575-1580.

34. Staudinger JL, Goodwin B, Jones SA et al. The nuclear receptor pxr is a lithocholic acid sensor that protects against liver toxicity. Proc Natl Acad Sci USA, 2001;98: 3369-3374.
35. Health NIo. 2014. Severity grading in drug induced liver injury. Available at: http:// livertox.nih.gov/Severity.html (accessed 5 October 2014).

36. Andrews E, Armstrong M, Tugwood J et al. A role for the pregnane $x$ receptor in flucloxacillin-induced liver injury. Hepatology, 2010;51:1656-1664.

37. Ng CS. A study of genetic polymorphism underlying idiosyncratic hepatotoxicity due to anti-tuberculosis medications. $\mathrm{PhD}$ thesis, Newcastle University, UK, 2012.

38. Russmann S, Kullak-Ublick GA, Grattagliano I. Current concepts of mechanisms in drug-induced hepatotoxicity. Curr Med Chem, 2009;16:3041-3053.

39. Xie W, Radominska-Pandya A, Shi Y et al. An essential role for nuclear receptors sxr/ pxr in detoxification of cholestatic bile acids. Proc Natl Acad Sci USA, 2001;98:3375-3380.

40. Li F, Lu J, Cheng J et al. Human pxr modulates hepatotoxicity associated with rifampicin and isoniazid co-therapy. Nat Med, 2013;19:418-420.

41. Nolan CM, Goldberg SV, Buskin SE. Hepatotoxicity associated with isoniazid preventive therapy: a 7-year survey from a public health tuberculosis clinic. JAMA, 1999;281: 1014-1018.

42. Chamorro JG, Castagnino JP, Musella RM et al. Sex, ethnicity, and slow acetylator profile are the major causes of hepatotoxicity induced by antituberculosis drugs. J Gastroenterol Hepatol, 2013;28:323-328.

43. Shu CC, Lee CH, Lee MC, Wang JY, Yu CJ, Lee LN. Hepatotoxicity due to first-line antituberculosis drugs: a five-year experience in a taiwan medical centre. Int J Tuberc Lung Dis, 2013;17:934-939.

44. Leise MD, Poterucha JJ, Talwalkar JA. Druginduced liver injury. Mayo Clin Proc, 2014;89:95-106.

45. Grattagliano I, Bonfrate L, Diogo CV, Wang $\mathrm{HH}$, Wang DQ, Portincasa P. Biochemical mechanisms in drug-induced liver injury: certainties and doubts. World J Gastroenterol, 2009;15:4865-4876.

46. Boelsterli UA, Lim PL. Mitochondrial abnormalities-a link to idiosyncratic drug hepatotoxicity? Toxicol Appl Pharmacol, 2007;220:92-107. 